\title{
PERSPEKTIF YURIDIS TANGGUNG J AWAB DOKTER TERHADAP RAHASIA MEDIS PASIEN HIV/AIDS (Studi di Rumah Sakit Umum Daerah Banyumas)*
}

\author{
Muhammad Taufiq \\ Fakultas Hukum Universitas J enderal Soedirman
}

\begin{abstract}
Examination of HIV/AIDS patient with do voluntary and confidential principle. Patient confidentiality must be maintained with the best. Status and the presence of HIV/AIDS patients are kept secret and so raises dilemma for physicians nor patient themselves. J uridical perspective of physician responsibility in opening the medical secret of patients with HIV/AIDS is a view or understanding of legal liability physicians in opening the medical secret of HIV/AIDS patients. Things must be secret maintained in the form of of identity, diagnosis, disease history, inspection history and treatment history. Perspective juridical physician's responsibility in RSUD Banyumas generally show very much agrees on opening medical confidential HIV/AIDS patients with patient consent. Implementation of medical confidentiality laws against HIV/AIDS patients in RSUD Banyumas implemented properly.
\end{abstract}

Key words : confidential medical, legal perspectives physicians, law enforcement

\begin{abstract}
Abstrak
Pemeriksaan pasien HIV/ AIDS dilakuan dengan azas sukarela dan rahasia. Kerahasiaan penderita harus dijaga dengan sebaik-baiknya. Status dan keberadaan pasien HIV/AIDS yang dirahasiakan menimbulkan dilema baik pada dokter yang merawat maupun pasien itu sendiri. Perspektif yuridis tanggung jawab dokter dalam membuka rahasia medis pasien HIV/ AIDS merupakan pandangan atau pemahaman dokter terhadap tanggung jawab hukum dalam membuka rahasia medis pasien HIV/ AIDS. Hal yang harus dijaga berupa identitas, diagnosis, riwayat penyakit, riwayat pemeriksaan dan riwayat pengobatan. Perspektif yuridis tanggung jawab dokter di RSUD Banyumas secara umum menunj ukkan sangat setuju dalam membuka rahasia medis pasien HIV/AIDS dengan seizin pasien. Implementasi hukum terhadap kerahasiaan medis pasien HIVI AIDS di RSUD Banyumas dilaksanakan dengan baik.
\end{abstract}

Kata kunci : rahasia medis, perspektif yuridis dokter, implementasi hukum

\section{Pendahuluan}

Visi Indonesia Sehat 2010 menetapkan segala pembangunan harus berwawasan kesehatan. Ajakan untuk memikirkan bagaimana caranya agar semua rakyat bisa hidup sehat, bahagia dan produktif. Program-program kesehatan harus diutamakan memelihara dan meningkatkan status kesehatan bukan hanya memberikan pengobatan kepada orang sakit seperti yang selama ini dilakukan. Sehingga pelayanan kesehatan tidak hanya bersifat kuratif saja tetapi meliputi preventif, promotif dan rehabilitatif.

\footnotetext{
- Artikel ini merupakan artikel hasil penelitian tesis pada Program Magister IImu Hukum Konsentrasi Hukum Kesehatan tahun 2011.
}

Berkenaan dengan pencegahan dan pengendalian penyakit menular seperti HIV/AIDS perlu memperhatikan hak-hak dan kewajiban pasien penyakit menular khususnya HIV/AIDS tersebut di tengah-tengah keluarga dan masyarakat. Kewajiban utama dari profesional masyarakat ilmu kesehatan maupun tenaga kesehatan adalah melindungi hak-hak pasien dengan menjaga kerahasiaan rekam medis pasien HIV/ AIDS. Kaidah turunan moral bagi tenaga kesehatan adalah privacy (berarti menghormati hak privacy pasien), convidentiality (berarti kewajiban menyimpan informasi kesehatan sebagai rahasia), fidelity (berarti kesetiaan) dan vera- 
city (berarti menjunjung tinggi kebenaran dan kejujuran). ${ }^{1}$

Era informasi sekarang ini, setiap orang harus dan berhak atas informasi yang menyangkut diri pribadinya. Sebagai akibat hak atas informasi dari pasien (the right to information) terdapat pula kewajiban dokter untuk memberikan informasi kepada pasiennya. Pasien berhak untuk memutuskan sendiri, untuk mempergunakan haknya atau tidak. Pemegang haklah yang berwenang untuk menentukan sebagai manifestasi dari hak otonomi (the right to selfdetermination). Kedua hak dasar tersebut bertolak dari hak atas perawatan kesehatan (the right to health care) yang merupakan hak asasi individu (individual human right). ${ }^{2}$

Adanya perkembangan bidang sosial dan budaya yang menyertai perkembangan masyarakat telah membawa perubahan terhadap status manusia sebagai obyek ilmu kedokteran menjadi subyek yang berkedudukan sederajat. Peningkatan status pasien sebagai subjek yang sederajat ini oleh Hipokrates dituangkan dalam suatu hubungan yang disebabkan sebagai transaksi terapeutik. Bagian penting dalam hubungan dokter pasien adalah kepercayaan. ${ }^{3}$ Untuk

Samsi Jacobalis, 2005, Pengantar Tentang Perkembangan IImu Kedokteran, Etika Medis, dan Bioetika, CV Sagung Seto bekerjasama dengan Universitas Tarumanegara, Jakarta, hlm. 75-76,; J ohn Adam RGN "Prescribing; The Ethical Dimension", Nurse Prescriber, 1(7), 2004, hlm. 1-3; J eryl S. Cohen, Jeanne M. Erickson, "Ethical Dilemmas and Moral Distress in Oncology Nursing Practice", Clinical J ournal of Oncology Nursing, Volume 10, Number 6/December 2006, hlm 775-780, John W. Seymour, dan Lawrence Rubin, "Principles, principals, and process $\left(\mathrm{P}^{3}\right)$ : A model for play therapy ethics problem solving", International Journal of Play Therapy, Vol 15(2), 2006, hlm. 101-123,; Vicki D. Lachman, "Practical Use of the Nursing Code of Ethics: Part I", MEDSURG Nursing,J anuary/ February 2009, Vol. 18/ No. 1, hlm. 56-57.

Oetama dan Fred Ameln, "Hukum Kedokteran dan Beberapa Hak Pasien", J ournal Cermin Dunia Kedokteran No. 22, 1981, hlm. 36. Lihat pula J. Guwandi, 2007, Hukum Medis, Jakarta: FKUI, hlm. 18,; Hargianti Dini Iswandari, "Aspek Hukum Penyelenggaraan Praktek Kedokteran: Suatu Tinjauan Berdasarkan Undang-Undang No. 9/2004 Tentang Praktek Kedokteran", J urnal Manajemen Pelayanan Kesehatan, Vol. 09, No.02, J uni 2006, hlm 54.

3 J ohn R. Williams, Medical Etics Manual, Terjemahan oleh Tim Penerjemah PSKI FK UMY, editor Sagiran, 2000, Pusat Studi Kedokteran Islam, UMY, hlm. 4,; Endang Kusuma Astuti, "Hubungan Hukum Antara Dokter dan Pasien Dalam Upaya Pelayanan Medis", Jurnal Legality, 2010, hlm 2,; Ali Roatib dkk, menerima perawatan medis, seorang pasien harus membuka rahasia kepada dokter mengenai informasi yang mungkin tidak ingin diketahui orang lain. Mereka memiliki alasan yang kuat mempercayai dan mempercayakan dirinya pada dokter, hal ini terjadi karena dokter telah dinyatakan sebagai seorang profesional. Kepercayaan ini mengandalkan kompetensi dan kesediaan dokter untuk mempedulikan pasien, sehingga seorang pasien harus bisa dengan perasaan lega dan aman serta tidak khawatir menaruh kepercayaan kepada dokternya, bahwa rahasia yang diceriterakan kepada dokter tidak akan diungkapkan lebih lanjut olehnya. Dengan demikian ia bebas dan sejuj urnya mau menceriterakan segala sesuatu yang dirasakan kepada dokter.

Hak atas rahasia medis adalah hak pasien yang merupakan hak pasien untuk meminta bahwa rahasia yang diceriterakan kepada dokternya tidak diungkapkan lebih lanjut. Namun pasien juga bisa mengizinkan sang dokter untuk mengungkapkan kepada pihak yang berkepentingan. Pasien pun bisa melepaskan haknya untuk memperoleh informasi sehingga memutuskan untuk tidak diberitahukan apa yang dideritanya.

Kasus-kasus tertentu, seorang dokter atau tenaga kesehatan bisa berada dalam keadaan dilema jika penyakit yang diderita pasien itu juga membahayakan masyarakat sekitarnya seperti HIV/ AIDS, sementara pasien tidak memberikan persetujuan untuk diungkapkan rahasianya. Kecuali sudah diwajibkan oleh undangundang atau peraturan yang lebih tinggi tingkatnya, maka dokter wajib melaporkan.

Pasal 48 UU No. 29 Tahun 2004 tentang Praktik Kedokteran dan Pasal 57 UU No. 36 Tahun 2009 tentang Kesehatan mengundang dilema, di satu sisi dokter atau tenaga kesehatan harus menyimpan rahasia medis pasien, disisi lain harus membuka rahasia pasien, sementara prinsip yang dianut secara universal pada saat ini dan diadopsi oleh Pemerintah Indonesia bah-

\footnotetext{
"Hubungan Antara Karakteristik Perawat dengan Motivasi Perawat Pelaksana dalam Menerapkan Komunikasi Terapeutik Pada Fase Kerja Di Rumah Sakit Islam Sultan Agung Semarang", Nurse Media J ournal of Nursing, Volume 1, Nomor 1, Tahun 2007, hlm 2,;
} 
wa pemeriksaan HIV/ AIDS pada setiap orang dengan azas sukarela dan rahasia (Keputusan Menteri Koordinator Bidang Kesejahtaraan Rakyat No. 9// KEP/ MENKO/ KESRA/ VI/ 1994 tentang Strategi Nasional Penanggulangan HIV/AIDS di Indonesia), artinya tidak dapat diwajibkan karena bertentangan dengan HAM sehingga perlu ada informed consentnya terlebih dahulu baik pemeriksaannya maupun membuka untuk diberitahukan kepada orang lain. ${ }^{4}$

Menurut J onathan Mann, AIDS meliputi tiga macam epidemi. ${ }^{5}$ Pertama, penyebaran HIV (Human Immunodeficiency Virus) yang penularannya terjadi melalui hubungan seksual (homo dan heteroseksual), dari lbu ke bayi dan melalui darah yang tercemar (transfusi, produk darah, pemakaian jarum suntik, dan sebagainya). Epidemi ini berlangsung secara diam-diam dan mungkin sekali telah dimulai tahun 1950-an. Darah tertua yang tercemar HIV berasal dari Zaire dalam tahun 1959. Jumlah orang yang terinfeksi kini telah mencapai sepuluh juta orang. Kedua, berjangkitnya AIDS yang mulai dikenal sejak tahun 1981 dan kini sudah mencapai lebih dari setengah juta penderita. Ketiga, epidemi yang bersifat sosial, yakni stigmatisasi, prasangka dan diskriminasi yang timbul akibat AIDS. Epidemi yang ketiga ini menimbulkan berbagai dilema dalam masyarakat yang mempersulit penanggulangan AIDS secara rasional.

Langkah-langkah klasik yang umum diambil untuk menanggulangi penyakit menular hanya penemuan penderita, pelaporan dan pencatatan penderita dan isolasi serta pengobatan penderita untuk menaggulangi AIDS. Sifat pelaporan dengan tetap merahasiakan identitas penderita. Maka dalam melakukan pemeriksaan HIV pada suatu populasi (orang-orang dengan gejala dan tanda konsisten dengan in-

\footnotetext{
Margarita M. Maramis, 2007, Konseling dan Tes Sukarela Untuk Penderita HIV \& AIDS dalam Nasronudin \& Margarita M. Maramis (editor), Konseling, Dukungan, Perawatan \& Pengobatan ODHA, Airlangga University Press, Surabaya, hlm. 7; Hargianti Dini Iswandari, op.cit, hlm 55.

5 Suriadi Gunawan, "Perkembangan Masalah AIDS", J ournal Cermin Dunia Kedokteran, No. 75, 1992, J akarta, hlm. 1. Lihat pula Steinbrook, M.D., "The AIDS Epidemic in 2004", The New England Journal of Medicine.
}

feksi HIV) baik melalui pemeriksaan dan konseling HIV (Voluntary Counselling and Testing/ VCT), pemeriksaan HIV diagnostik, diindikasikan pada pasien dengan tanda dan gejala yang sejalan dengan penyakit-penyakit yang terkait HIV/ AIDS, termasuk pemeriksaan terhadap tuberkulosis sebagai pemeriksaaan rutin, pemeriksaan HIV dengan inisiatif dari tenaga kesehatan (Provider-Initiated Testing and Counselling/ PITC) harus ada informed consentnya. Kecuali pemeriksaan HIV wajib yang dibutuhkan sebelum dilakukannya prosedur-prosedur yang berkaitan dengan pemindahan cairan atau jaringan tubuh, jika hasilnya positif terkena HIV maka identitas pemberi donor tetap harus dirahasiakan. $^{6}$

Instruksi Menteri Kesehatan No. 72/ MenKes/Inst/ 1988 tentang Kewajiban Melaporkan Penderita Dengan Gejala AIDS. Ketentuan tersebut hanya ditujukan kepada petugas kesehatan dan sarana pelayanan kesehatan saja. Tindakan yang diambil pada saat ditemuinya seseorang dengan gejala AIDS hanyalah pelaporan kepada Dirjen P2MPLP (Pemberantasan Penyakit Menular dan Penyehatan Lingkungan Pemukiman) saja dengan memperhatikan kerahasiaan pribadi pasien sementara lingkungan tidak diberitahu kalau ada pasien penderita HIV/ AIDS dengan alasan HAM dan kemungkinan besar bisa menular berarti akan menimbulkan masalah HAM di masyarakat.

Menurut Direktur Pengendalian Penyakit Menular Langsung Dirjen P2MPLP Kementrian Kesehatan estimasi ODHA (orang dengan HIV/ AIDS) di Indonesia pada 2009 mencapai 186.000 orang dimana urutan pertama DKI 42.880 orang disusul Jatim 27.063 orang, Papua 23.439 orang, Jabar 23.423 orang dan J ateng 10.816 orang di urutan ke lima. ${ }^{7}$ Dari sebagian penderita HIV/ AIDS yang berada di J ateng yang bertempat tinggal di Banyumas ada yang berobat ke VCT Rumah Sakit Umum Daerah Banyumas

\footnotetext{
Dirjen Bina Pelayanan Medis Kementrian Kesehatan Republik Indonesia, 2010, Skrining HIV di Rumah Sakit Dalam Upaya Pencegahan Penyebaran HIV (Hasil Kajian Tahun 2009), hlm. 23-29.

7 HM. Subuh, 2010, Achieve Universal To HIV Prevention, Treat ment, Care and Support, Disampaikan pada Pertemuan IImiah Tahunan (PIT 1) MHKI, Jakarta, 21 Nopember 2010.
} 
sejumlah 180 orang. Terdiri dari 109 orang lakilaki dengan distribusi usia 1-14 tahun ada tiga orang, usia 20-24 tahun ada 13 orang, usia 2549 tahun ada 87 orang dan 50 tahun keatas ada 6 orang. Sedangkan perempuan terdiri dari 71 orang dengan dis-tribusi usia 1-14 tahun ada 2 orang, usia 15-19 tahun ada 4 orang, usia 20-24 tahun ada 17 orang, usia 25-49 tahun ada 46 orang dan usia 50 tahun ke atas ada 2 orang. Mereka ter-tular melalui transmisi (Injection Drug User/IDU) 22 orang, heteroseks 133 orang, homoseks 7 orang, WPS (wanita pekerja seks) 4 orang, perinatal 6 orang dan lain-lain 9 orang. Mereka ada yang bekerja sebagai TKI/TKW 1 orang, pelajar/mahasiswa 7 orang, swasta 51 orang, wiraswasta 21 orang, WTS 10 orang, buruh 14 orang ibu rumah tangga 17 orang, lainlain 4 orang dan yang tidak bekerja 55 orang. ${ }^{8}$

Status dan keberadaan pasien HIV/AIDS yang dirahasiakan dan lingkungan tidak diberitahu menimbulkan dilema dalam menghadapi pasien HIV/ AIDS baik pasien itu sendiri maupun dokter yang merawat. Apabila penderita memberitahukan kepada orang lain terutama kepada pasangannya, maka orang tersebut kemungkinan akan dicap sebagai orang yang tidak bermoral dan akan memperoleh hukuman sosial. Apabila penderita tidak memberitahukan kepada orang lain, terutama kepada pasangan hubungan seks, maka berarti ia ikut menyebarkan penyakit tersebut kepada orang lain. Apabila dokter memberitahukan kepada orang lain berarti melanggar hak pasien dan juga melanggar kode etik. Sebab dokter wajib menyimpan rahasia pasien termasuk penyakitnya. Apabila dokter tidak memberitahukan penyakit penderita kepada orang lain, terutama kepada keluarga penderita, maka berarti melanggar hak orang lain untuk dilindungi dari tertularnya penyakit dari orang lain. Dengan diberitahukan, maka mata rantai penyebaran akan bisa diputuskan sehingga tidak menambah jumlah penderita HIV/ AIDS. Namun karena masalah ini menyangkut rahasia medis, maka tanpa izin pasien, dokter tidak bisa berbuat apa-apa.

8 Klinik VCT RSUD Banyumas (Data bulan J anuari Tahun 2011).

\section{Permasalahan}

Ada dua permasalahan yang akan dibahas dalam artikel ini. Pertama, mengenai perspektif yuridis tanggung jawab dokter dalam membuka rahasia medis pasien HIV/AIDS; dan kedua, mengenai implementasi hukum terhadap kerahasiaan medis pasien HIV/AIDS dalam pelayanan kesehatan di Rumah Sakit Umum Daerah Banyumas.

\section{Metode Penelitian}

Penelitian ini merupakan penelitian kuantitatif dan kualitatif dengan pendekatan yuridis sosiologis. Subjek penelitian ini adalah 30 (tiga puluh) dokter yang dipilih dengan metode pengambilan sampel simple random sampling. Lokasi penelitian di RSUD Banyumas. Data yang diperlukan dalam penelitian ini adalah data primer dan data sekunder. Pengumpulan data primer dilakukan melalui angket dan wawancara, sedangkan data sekunder dikumpulkan meIalui metode studi kepustakaan. Data dianalisis dengan menggunakan metode kuantitatif dan kualitatif. Analisis kuantitaif dengan model analisis statistik sederhana, sedangkan analisis kualitatif dengan model content analysis.

\section{Hasil Penelitian dan Pembahasan}

AIDS atau Aqquiired Immune Deficiency Syndrome adalah suatu sindrom (kumpulan gejala) yang menyebabkan turunnya/hilangnya sistem kekebalan tubuh manusia. AIDS adalah tahap akhir dari infeksi virus HIV ketika sistem kekebalan tubuh sangat rusak, sehingga tidak dapat melawan infeksi ringan sekalipun dan pada akhirnya menyebabkan kematian. AIDS disebabkan oleh HIV $^{9}$ (Human Immunodefeciency Virus), yaitu virus yang dapat merusak system

\footnotetext{
Kementrian Negara Pemberdayaan Perempuan RI., 2008, Pemberdayaan Perempuan dalam Pencegahan Penyebaran HIV-AIDS, Jakarta, hlm. 17. Lihat pula Nasronudin dan Margarita M. Maramis, op.cit, hlm. 192,; Ade Kusmiadi, Pengintegrasian pendidikan pencegahan HIB AIDS dalam satuan program pendidikan nonformal dan informal, J urnal IImiah VISI PTK-PNF, Vol.3 No.2, 2008, hlm 150. Lihat pula Farah Nurbani, "Dukungan Sosial Pada ODHA", J urnal Yayasan Spiritia Universitas Gunadarma, 2006, hlm. 36, ; Ade Kusmiadi, "Pengintegrasian pendidikan pencegahan HIB AIDS dalam satuan program pendidikan nonformal dan informal", Jurnal IImiah VISI PTK-PNF, Vol.3 No.2, 2008, hlm 150.
} 
kekebalan tubuh manusia. HIV ditemukan pada cairan-cairan tubuh terutama semen, cairan vagina dan darah. HIV hanya dapat berkembang biak pada sel hidup. Penularan penyakit HIV melalui kontak dengan cairan tubuh yang mengandung sel terinfeksi atau partikel virus. HIV ditularkan melalui ${ }^{10}$ hubungan seksual dengan penderita, dimana selaput lendir mulut vagina atau rektrum berhubungan langsung dengan cairan tubuh yang terkontaminasi; suntikan atau infus darah yang terkontaminasi, seperti yang terjadi pada transfusi darah, pemakaian jarum bersama-sama atau tidak sengaja tergores oleh jarum yang terkontaminasi virus HIV; pemindahan virus dari ibu yang terinfeksi kepada anaknya sebelum atau selama proses kelahiran atau melalui ASI.

Cara-cara pencegahan penyebaran HIV/ AIDS antara lain: ${ }^{11}$ untuk orang sehat adalah abstinens (tidak melakukan hubungan seksual) dan seks aman (terlindung); untuk penderita HIV positif antara lain abstinens, seks aman, tidak mendonorkan darah atau organ, mencegah kehamilan, dan memberitahu mitra seksualnya sebelum dan sesudah diketahui terinfeksi; untuk penyalahguna obat-obatan adalah menghentikan penggunaan suntikan bekas atau bersama-sama dan mengikuti program rehabilitasi; untuk professional kesehatan adalah menggunakan sarung tangan lateks pada setiap kontak dengan cairan tubuh dan menggunakan jarum sekali pakai.

Berdasarkan penelitian mengenai perspektif yuridis tanggung jawab dokter dalam membuka rahasia medis pasien HIV/AIDS di RSUD Banyumas diperoleh suatu gambaran dari responden yang berjumlah 30 orang menunjukkan jawaban sangat setuju sebanyak 24 orang $(80 \%)$, menunjukkan jawaban setuju sebanyak 6 orang $(20 \%)$, sedangkan jawaban kurang setuju, tidak setuju dan sangat tidak setuju tidak ada. Dari hasil wawancara diperoleh gambaran

10 Sarjaini Jamal, "Pengetahuan Masyarakat Tentang HIV/ AIDS", J urnal Kedokteran YARSI, 13 (2) 2005, hlm. 218 226

11 Ratna Mahdiana, Ibid, hlm. 207-208. Lihat pula Dir.Jen. P2MPLP, 1997, AIDS Petunjuk Untuk Petugas Kesehatan, Dep.Kes.R.l. Jakarta, hlm. 120. Seokidjo Notoatmodjo, 2010, Etika \& Hukum Kesehatan, Rineka Cipta, J akarta, hlm. 130-131. bahwa perspektif yuridis tanggung jawab dokter dalam membuka rahasia medis pasien HIV/ AIDS di RSUD Banyumas menunjukkan sesuai dengan undang-undang yang berlaku. Dengan demikian dapat dikatakan bahwa secara umum gambaran tentang perspektif yuridis dokter dalam membuka rahasia medis pasien HIV/ AIDS adalah sangat setuju dan sesuai dengan peraturan perundang-undangan yang berlaku. Berarti dokter sebagai pemegang peran memiliki perspektif yuridis dalam membuka rahasia medis pasien HIV/AIDS memahami hak pasien yang sekaligus merupakan kewajiban dokter.

Cara pandang atau pola pikir dokter tentang pasien HIV/ AIDS memiliki hak atas rahasia medis. Dari hasil wawancara diperoleh informasi:

“... kami terbiasa mendapatkan sosialisasi peraturan yang berkaitan dengan tugas kami, sehigga kami memberikan pelayanan secara profesional sesuai regulasi yang berlaku dan tidak akan membedakan pasien HIV/ AIDS atau bukan, hasil test HIV/AIDS selalu kami jaga dan tidak dibocorkan kecuali kepada pasien yang bersangkutan, apabila kami membuka harus izin pasien, kami tidak berani membuka rahasia medis tanpa seizin pasien. Kami harus menjaga privacy dan kerahasiaan penyakit yang diderita pasien termasuk data medisnya."

Dokter sebagai pemegang peran dalam pelayanan kesehatan wajib merahasiakan segala sesuatu yang dilihat, didengar, dimengerti atau dijabarkannya mengenai pasiennya (Pasal 51 huruf e). Hak atas rahasia pada hakekatnya milik pasien. Dokter harus menghormati privacy pasien. Isi rekam medis hakekat di dalamnya terdapat rahasia medis adalah hak pasien (Pasal 52 huruf e UU No. 29 Tahun 2004). Dokter tidak memiliki hak atas rahasia medis melainkan mem-punyai kewajiban, yakni untuk berdiam diri bila ia dipanggil selaku saksi di pengadilan. Di depan hakim ia mempunyai hak untuk berdiam diri mengenai apa yang ia harus rahasiakan. Hal ini yang disebut hak mengundurkan diri.Menurut Talcot Parsons sebagai- 
mana dikutip oleh Agus Setiaman ${ }^{12}$ perspektif struktural fungsional memiliki ciri pokok yakni gagasan tentang kebutuhan masyarakat (societal needs). Masyarakat sangat serupa dengan organisme biologis, karena mempunyai kebutuhan-kebutuhan dasar yang harus dipenuhi agar masyarakat dapat melangsungkan keberadaannya atau setidaknya berfungsi dengan baik. Ciri dasar kehidupan sosial struktur sosial muncul untuk memenuhi kebutuhan-kebutuhan masyarakat dan me-respon terhadap permintaan masyarakat sebagai sistem sosial. Asumsinya adalah ciri-ciri sosial yang ada memberi kontribusi yang penting dalam mempertahankan hidup dan kesejahteraan seluruh masyarakat atau subsistem utama dari masyarakat tersebut. Masyarakat mempunyai kelembagaan yang saling terkait dan tergantung satu sama lain. Setiap lembaga dalam masyarakat melaksanakan tugas tertentu untuk stabilitas dan pertumbuhan masyarakat tersebut. Konsep keseimbangan terhadap permintaan masyarakat untuk terjaga dari tertularnya HIV/AIDS, sehingga meminta dokter untuk memberitahu lingkungan dengan cara membuka rahasia medis pasien HIV/ AIDS dan penderita HIV/AIDS harus dijaga kerahasiannya agar tidak diberitahukan ke lingkungan adalah menimbulkan keadaan "cognitive dissonance".

Hasil wawancara lain menyebutkan bahwa

“... kami bingung harus menjaga rahasia medis pasien HIV/AIDS sementara kami harus membuka baik karena permintaan penegak hukum atau atas perintah undang-undang. Namun akhirnya kami mengambil keputusan untuk mengundurkan diri jika menjadi saksi, kami lebih baik menjaga kepercayaan yang diberikan oleh pasien kepada kami. Persetujuan pasien sebagai dasar kami bertindak."

12 Agus Setiaman, perspektif sosiologis, http:// wordpress com/2008/11/25/ diakses tanggal 29 Desember 2010,; Bintang Hanggoro Putra, Fungsi dan Makna Kesenian Barongsai Bagi Masyarakat Etnis Cina Semarang, Harmonia, Volume 9. No. 1 (2009), hlm 26,; Ema Khotimah, "Analisis Kritis Teori Pembangunan dan Kedudukan Perempuan dalam Perspektif Ekofeminisme", J urnal Kajian Gender, Vol 1, No 1 (2010) , hlm 46
Menurut teori disonansi kognitif Festinger sebagaimana dikutip oleh Mar' ${ }^{1}{ }^{13}$ bahwa unsur kognitif adalah setiap pandangan/perspektif, pengetahuan, opini atau kepercayaan mengenai diri sendiri atau mengenai perilakunya. Sedangkan disonansi menggambarkan inkonsistensi antara dua atau lebih unsur kognitif. Hubungan antara unsur kognitif dapat berupa hubungan relevan atau berupa hubungan tidak relevan.

Ketika manusia bergerak maju dari berpikir mengenai bersikap dengan suatu cara tertentu, membentuk intensi perilaku, menetapkan tujuan perilaku dan menindaklanjuti secara aktual perilaku tersebut. Awalnya manusia belajar dengan mengamati perilaku orang lain, pemandangan belajar itu direpresentasikan ke dalam pikiran, dan kemudian, akhirnya diwujudkan dalam perilaku yang sama. Representasi kognitif adalah jembatan mutlak antara observasi yang dilakukan individu dengan tindakantindakan mereka. Sikap seseorang konsisten dan orang itu berbuat sesuatu sesuai dengan pandangan/ perspektif dan sikapnya. Oleh karena itu seseorang cenderung untuk tidak akan mengambil pandangan/perspektif dan sikap yang bertentangan satu sama lain dan cenderung untuk menghindari tindakan yang tidak sesuai dengan pandangan/perspektif dan sikapnya. Disonansi kognitif terjadi ketidaksesuaian di antara pandangan/perspektif dan sikap dengan perbuatan atau kenyataan.

Ketidakseimbangan yang menyebabkan disonansi kognisi yakni adanya dua elemen kognisi yang saling tidak sesuai yang dimiliki dokter bahwa dokter harus menjaga rahasia medis dalam rangka melindungi pasien HIV/ AIDS dan sekaligus harus membuka rahasia medis pasien HIV/ AIDS untuk melindungi masyarakat dari tertularnya HIV/ AIDS se-bagaimana diatur Pasal 48 UU No. 29 Tahun 2004 jo. Pasal 57 UU No. 36 Tahun 2009. Agar dokter seimbang lagi kognisi perspektif yuridis tanggung jawabnya maka

13 Mar'at, 1981, Sikap Manusia Perubahan Serta Pengukurannya, Bandung: Ghalia Indonesia, hlm. 45; Edwin Japarianto, "Analisis Pembentukan Disonansi Kognitif Konsumen Pemilik Mobil Toyota Avanza", J urnal Manajemen Pemasaran, Vol. 1, No. 2, Oktober 2006, hlm 83,; Hendra Poerwanto, "Mengevaluasi Kualitas Layanan Jasa dengan Menggunakan Model 4D", Jurnal Manajemen \& Kewirausahaan Vol. 2, No. 2, September 2000, hlm 61. 
dokter dapat mengundurkan diri apabila menjadi saksi sehingga dokter tidak membuka rahasia medis yang harus ia jaga sementara sang dokter tidak bersalah sesuai hukum yang ada sebagaimana diatur dalam Pasal 170 KUHAP. Hak ingkar yang dimiliki dokter pada hakekatnya merupakan penegasan kewajiban menyimpan rahasia medis yang harus dijaga. Pengaturan kewajiban menyimpan rahasia bertujuan bukan hanya melindungi kerahasiaan orang seorang secara pribadi akan tetapi juga menjaga kepentingan umum dan berlangsungnya profesi kepercayaan tersebut. Sekalipun pasien dalam memberikan persetujuannya tanpa banyak pertimbangan bukan berarti bahwa yang wajib menyimpan rahasia seenaknya saja dapat meneruskannya kepada pihak lain. Di sini betul-betul yang punya kerahasiaan itu dan oleh karena itu dapat juga melepaskan haknya, akan tetapi pasien sama sekali tidak mempunyai kewenangan perihal kewajiban menyimpan rahasia. Sebaliknya kewenangan ini justru ada pada dokter selaku penyandang profesi. Hanya dokter yang dapat menentukan sejauh mana persetujuan pasien dapat dimanfaatkan.

Berkaitan dengan rekam medis pasien HIV/AIDS, diperoleh informasi dari informan sebagai berikut:

“... kami selalu mencatat hal-hal yang berkaitan dengan pasien HIV/AIDS, baik hal ikhwal gejala-gejala sakit dan penyakitnya yang dirasakannya serta tindakan yang perlu kami ambil. Kami membuat rekam medis secara lengkap dan jelas serta berkesinambungan. Rekam medis harus kami isi catatan dan dokumen mengenai identitas pasien, pemeriksaan, pengobatan, tindakan dan pelayanan lain yang telah diberikan kepada pasien. Rekam medis milik sarana pelayanan kesehatan sedangkan isinya milik pasien."

Pemikiran dokter tentang hak pasien HIV/ AIDS atas informasi adalah hak untuk mendapat informasi mengenai penyakitnya dan tentang aturan-aturan yang berlaku di rumah sakit tempat ia berobat, dan nama dan keahlian dokter lain yang dapat mengobatinya. Seorang pasien juga mempunyai hak atas jawaban terhadap pertanyaan yang ia ajukan kepada dokter.
Hanya informasi tertentu yang dapat dirahasiakan dokter hal itu demi kepentingan pasien. Dapat juga terjadi dokter tidak memberikan keterangan atau merahasiakan tentang penyakit pasien karena ia tidak pasti diagnosisnya. Di samping pasien mempunyai hak atas informasi baik yang diminta maupun yang tidak, juga mempunyai hak untuk mendapat keterangan yang benar. Dengan demikian dokter sebagai pemegang peran dalam pelayanan kesehatan tidak saja harus memberikan informasi atas pertanyaan pasien, ia juga harus memberikan keterangan yang benar. Apabila dokter tidak memberikan keterangan yang benar maka ia wajib memper-tanggungjawab kannya. Dalam hubungan ini yang menjadi pertimbangan bahwa seorang dokter tidak wajib memberikan informasi yang benar ataupun sama sekali tidak memberikan atau merahasiakan informasi, jika hal itu didasarkan atas suatu terapi atau jika hal itu akan merugikan pasien.

Berkaitan dengan pemikiran dokter tentang pasien HIV/ AIDS mempunyai kebebasan dan otonomi untuk menentukan kehendaknya sebagai dasar hak pasien dalam pelayanan kesehatan, dari hasil wawancara diperoleh informasi sebagai berikut:

“... kami membebaskan pasien HIV/AIDS untuk berhubungan dengan keluarga mau pun untuk beribadah. Kami membebaskan pasien untuk minta pendapat dokter lain di rumah sakit ini. Kami memahami bahwa pasien HIV/AIDS mempunyai hak untuk menolak pengobatan sehingga kami sebelum mengobati minta persetujuan pasien terlebih dahulu. Sebelum test dilakukan kami terlebih dahulu minta persetujuan pasien. Hasil test selalu kami jaga dan tidak dibocorkan kecuali kepada pasien yang bersangkutan, apabila kami membuka harus izin pasien. Kami tidak berani membuka rahasia medis tanpa seizin pasien."

Dokter sebagai pemegang peran dalam pelayanan kesehatan wajib menghormati kebebasan pasien HIV/ AIDS untuk menentukan kehendak. Persetujuan yang diberikan oleh pasien merupakan titik tolak untuk membicarakan keterangan-keterangan yang merupakan rahasia medis dengan pihak lain semata-mata dilaku- 
kannya karena bermanfaat bagi diri pasien. ${ }^{14}$ Kepentingan pasien tersebut harus dijadikan pedoman kerja bagi dokter dalam pembahasanpembahasan, akan tetapi hanya menyangkut hal-hal yang sungguh-sungguh perlu untuk diungkap kan dan tentunya hanya kepada mereka yang berkepentingan dalam bidang pelayanan kesehatan termasuk konsultasi dan penunjang pelayanan.

Pasien harus dengan rasa bebas dapat mengemukakan hal ikhwal gejala-gejala sakit dan penyakitnya yang dirasakannya dengan jelas dan dalam bahasa yang dapat dimengerti demi kepentingan pasien sendiri. Sebaliknya dokter setelah mencerna informasi riil tersebut, dokter wajib menyampaikan kepada pasien pendapatnya. Dokter harus pula mengiinformasikan pasien mengenai rencana pengobatan dan perawatan, berapa lama pengobatan dan perawatan itu akan ber-langsung dan efek-efek yang perlu diantisipasi, seperti ketidaknyamanan yang akan dialami, dan sebagainya yang merupakan hak pasien (Pasal 52 huruf (a) UU No. 29 Tahun 2004). Informasi yang telah diterima oleh kedua belah pihak - pasien atau dokter selanjutnya dijadikan dasar keputusan yang dapat dipertanggungjawabkan dan dituangkan dalam bentuk informed consent. Maka ketika dokter akan mengambil tindakan medis yang berisiko tinggi memerlukan persetujuan tertulis dan ditandatangi oleh yang berhak memberikan persetujuan (Pasal 3 ayat 1 Permenkes 585/ 1989 tentang Persetujuan Tindakan Medis).

Implementasi Hukum terhadap Kerahasiaan Medis Pasien HIV/ AIDS dalam Pelayanan Kesehatan di RSUD Banyumas diperoleh suatu gambaran dari responden yang berjumlah 30 orang menunjukkan jawaban sebanyak 24 orang $(80 \%)$ sangat baik, menunjukkan jawaban baik se-banyak 6 orang (20\%), sedangkan cukup baik, tidak baik dan sangat tidak baik tidak ada. Dari hasil wawancara diperoleh gambaran bahwa

14 Freddy Tengker, 2007, Hak Pasien, Bandung: Mandar Maju, hlm. 53; Setiati Widihastuti, "Kajian Perlindungan Hak Pasien Sebagai Pencegahan Malpraktek Medik", J urnal Penelitian Humaniora, Volume. 13, No. 2, Oktober 2008, hlm 60; Harvensica Gunnara, "Perlindungan hak pasien di RS Kanker Dharmais Jakarta", J urnal Kesehatan Masyarakat Nasional, Vol. 02, No. 03, 2007, hlm 137, implementasi hukum terhadap kerahasiaan medis pasien HIV/ AIDS di RSUD Banyumas menunjukkan sesuai dengan undang-undang yang berlaku. Hal ini dapat dilihat dari informasi yang berkaitan pelayanan kesehatan yang diberikan dengan selalu adanya persetujuan tindakan medis, rekam medis dan rahasia medis serta sanksi bagi dokter yang tidak sesuai dengan peraturan yang berlaku. Dengan demikian dapat dikatakan bahwa secara umum gambaran tentang implementasi hukum terhadap kerahasiaan medis pasien HIV/ AIDS dalam pelayanan kesehatan di RSUD Banyumas dapat dikatakan sangat baik dan sesuai dengan peraturan perundang-undangan yang berlaku.

Setiap anggota masyarakat sebagai pemegang peran ditentukan tingkah lakunya oleh pola peranan yang diharapkan daripadanya baik oleh norma-norma hukum maupun oleh kekuatan-kekuatan di luar hukum. ${ }^{15}$ Demikian juga dokter sebagai pemegang peran, memiliki kewajiban untuk menjaga rahasia medis pasien HIV/AIDS merupakan aturan yang di-buat dan diterapkan oleh pemerintah kepada dokter, sehingga tidak ada alasan apriori mengapa hukum tidak dapat beradaptasi dengan segera terhadap perubahan-perubahan lingkungannya. Sedangkan peranan dari kekuatan sosial, yang tidak hanya berpengalaman terhadap dokter sebagai sasaran yang diatur oleh hukum, melainkan terhadap lembaga-lembaga hukum, dalam kekuatan sosial ini termasuk kompleks suatu tatanan lainnya. Hasil akhir dari implementasi hukum terhadap kerahasiaan medis pasien HIV/ AIDS tidak hanya dimonopoli oleh hukum. Artinya, tingkah laku dokter tidak hanya ditentukan oleh hukum, melainkan ditentukan oleh kekuatan sosial lainnya, seperti perspektif yuridis tanggung jawab dokter, kepentingan lingkungan dan lain sebagainya.

Menurut azas menghormati otonomi pasien (Principles of Primacy of Patiens's Autono-

\footnotetext{
15 Adi Sulistyono et. all., "Hukum dan Kebijakan Kemiskinan", Jurnal J urisprudence, Volume 2. No. 1 Maret 2005, hlm. 8; Khudzaifah Dimyati, "Hukum dan Kebijakan Kemiskinan: Studi Tentang Produk Legislatif Daerah Sebagai Sarana Penanggulangan Kemiskinan", Jurnal Ilmu Hukum, Vol. 9, No. 1, Maret 2006, hlm 7.
} 
my). ${ }^{16}$ Bahwa pasien adalah bebas untuk menentukan nasibnya sendiri (self determination), dalam arti dia oleh hukum dianggap memiliki kapasitas untuk menentukan pilihannya sendiri secara rasional, karena itu dokter wajib menghormati kehendak pasiennya. Tentu saja prinsip ini hanya berlaku jika pasien tersebut dalam keadaan normal dan mempunyai kapasitas sebagai subyek hukum yang cakap berbuat. Keinginan pasien harus dihormati oleh dokter meskipun mungkin pendapat pasien nyata-nyata salah, tentu dengan kewajiban dokter menjelaskan apa yang benar menurut pengetahuan, profesionalisme, dan keyakinan dari dokter tersebut. Dokter harus jujur terhadap pasiennya, memberdayakan pasien untuk membuat keputusan berdasarkan informasi tentang rencana perawatan dan pengobatannya. Keputusan pasien tentang perawatannya merupakan hal yang paling utama, selama kepatutan tersebut tidak melanggar etik dan tidak mengarah pada permintaan yang tidak semestinya. Pada akhirnya pendapat pasien yang harus dituruti, sejauh tidak bertentangan dengan ketertiban umum. Jika pasien tidak mengijinkan sang dokter untuk mengetahui lebih jauh tentang status posisitif HIV pasien melalui test maka dokter tidak bisa memaksa. Sekalipun kehendak pasien didasari atas alasan yang nyata-nyata salah dan bahkan mungkin dapat menyebab kan kematian pasiennya.

Menurut azas konfidensialitas, ${ }^{17}$ kewaj iban dokter untuk menjaga rahasia medis pasien HIV/ AIDS bukan hanya sekedar didasarkan pada sumpah saja untuk merahasiakan penyakit pasien sehingga merupakan kewajiban moral dan untuk mematuhinya sangat tergantung pada pribadi masing-masing dokter. Tidak adanya sanksi yang bersifat memaksa yang dapat diterapkan bagi dokter yang melanggarnya selain sanksi pengucilan oleh masyarakat kedokteran. Timbul pemikiran untuk menjadikan kewajiban

16 Munir Fuady, 2005, Sumpah Hippocrates (Aspek Hukum Malpraktik Dokter), Bandung: PT. Citra Aditya, hlm. 6, Endang Kusuma Astuti, op.cit, hlm 3, Hargianti Dini Iswandari, op. cit, hlm 54.

17 Sunny Ummul Firdaus, 2008, Rekam Medik Dalam Sorotan Hukum dan Etika, Surakarta: Sebelas Maret University Press, hlm. 45. menyimpan rahasia kedokteran tidak hanya sekedar kewajiban moral tetapi juga kewajiban hukum. Maka masalah konfidensialitas perlu dikuatkan dengan peraturan perundang-undangan dan menjadi kewajiban hukum sehingga ada sanksi yang bersifat paksaan dan dapat diterapkan terhadap dokter yang melanggar norma tersebut, karena sanksi hukum merupakan suatu cara penerapan norma atau peraturan. ${ }^{18} \mathrm{~J}$ adi sanksi hukum sebagai sanksi-sanksi yang digariskan atau diotorisasi oleh hukum. Setiap peraturan hukum mengandung statemen konsekuensi-konsekuensi hukum yang berupa sanksi agar dapat dibedakan antara yang patuh dengan yang melanggar peraturan hukum.

Perlu disadari bahwa terwujudnya kesehatan yang baik hanya dapat dicapai jika tiap orang dengan perasaan bebas dapat pergi ke dokter dan menceriterakan dengan hati terbuka segala keluhannya. Semuanya ini dimungkinkan jika setiap orang yang menaruh kepercayaan kepada dokter bahwa penyakitnya tidak akan diungkapkan kepada orang lain. Jika kepercayaan tidak ada mustahil orang menjadi segan berobat sehingga penyakit yang ada di masyarakat tidak dapat diketahui dan dikontrol. Pemikiran yang berorientasi pada azas otonomi dan azas konfidensialitas tersebut di atas maka pada waktu akan melakukan testing untuk diagnosa HIV selalu harus secara sukarela, hasilnya dirahasiakan dan disertai dengan konseling sebelum dan sesudah testing (Voluntary Counselling and Testing). Konseling memegang peranan yang sangat penting untuk membantu mereka yang takut (baik beralasan maupun tidak), mereka yang sudah terinfeksi (HIV positif), istri/suami/ pasangannya, dan bila perlu keluarga dan lingkungan pergaulannya yang terdekat sebagaimana yang dijelaskan dalam Lampiran Keputusan Menko Kesra No. 9/ KEP/ MENKO/ KESRA/ Vl/ 1994 tentang Strategi Nasional Penanggulangan HIV/ AIDS di Indonesia.

Berbeda dengan di negara lain seperti di Amerika Central for Disease Control and Prevention $(C D C)$ menetapkan bahwa setiap orang

18 Lawrence, M. Fiedman, (alih bahasa M Khozim), 2009, Sistem Hukum Perspektif IImu Sosial, Bandung: NusaMedia, hlm. 93. 
yang berumur 13 tahun sampai 64 tahun yang hendak berobat di rumah sakit harus di-periksa status HIV/AIDSnya yang sebelumnya bersifat sukarela. ${ }^{19}$ Di India misalnya, Supreme Court India telah memutuskan bahwa orang yang sadar dihinggapi AIDS, akan menikah, dan menularkan penyakit tersebut adalah pelanggaran hukum dan bisa dikenakan hukuman denda dan penjara sampai 2 tahun. ${ }^{20}$

Diberlakukannya Peraturan Pemerintah No. 10 Tahun 1966 tentang Waj ib Simpan Rahasia Medis kewajiban moral untuk menjaga rahasia medis berubah menjadi kewajiban hukum. Pasal 48 UU No. 29 Tahun 2004 jo. Pasal 57 UU No. 36 Tahun 2009, dengan tegas bahwa rahasia kedokteran merupakan hak pasien yang wajib dihormati. Rahasia kedokteran hanya dapat dibuka untuk kepentingan kesehatan pasien, memenuhi aparatur penegak hukum, permintaan pasien sendiri, atau berdasarkan ketentuan undang-undang, merupakan pengecualian kewajiban dokter terhadap konfidensialitas pasien.

Wajib simpan rahasia merupakan suatu perintah yang diperoleh atas dasar jabatan yang diemban. Namun manakala keadaan menentukan lain maka perintah inipun bisa berubah dan disimpangi. Rahasia kedokteran ini dijaga dengan sangat baik oleh pelaku profesi tidak semata-mata untuk kepentingan jabatan saja tetapi lebih dari itu untuk menghindarkan pasien dari hal-hal yang merugikan karena terbongkarnya status kesehatannya. Seperti pasien HIV terancam kehilangan pekerjaannya karena sebagian rekannya takut tertular setelah mengetahui ada seorang penderita HIV/AIDS di lingkungan mereka.

Alasan kemanusiaan biasanya menjadi hal utama yang digunakan sebagai landasan kewajiban menyimpan rahasia medis pasien HIV/ AIDS. Namun segala bentuk dispensasi terhadap pasal ini dicari celahnya dan disalahgunakan untuk kepentingan lain yang kurang dapat

19 J. Guwandi, 2009, Pengantar IImu Hukum Medis dan Bioetika, J akarta: FKUI, hlm. 75.

20 Ibid, hlm. 76. Lihat pula Shaukat Muhamad, 2010, "The Interface between the Family and the Health Care System in the Care of People With HIV/AIDS", J ournal of Health Management, September 1. 2010. dipertanggungjawabkan. Oleh karena itu perlu ada konsolidasi dan penyamaan perspektif antara pelaku profesi kesehatan dengan para penegak hukum, sampai sejauh mana penyimpangan dapat ditoleransi dan sampai sejauh mana kewajiban harus tetap dipertahankan.

Hal yang berkait dengan penyimpangan bahwa rahasia medis pasien HIV/ AIDS dapat di buka jika memenuhi beberapa syarat. ${ }^{21}$ Pertama, keadaan memaksa (Overmacht) sebagaimana diatur dalam Pasal 48 KUHP. Overmacht yang dimaksud di dalam Pasal 48 KUHP ini adalah overmacht nisbi, dimana terdapat konflik kejiwaan pada pelakunya ketika menghadapi kondisi darurat, sehingga harus segera mengambil keputusan meskipun keputusan tersebut melanggar hukum untuk mengatasi konflik kejiwaannya tersebut. ${ }^{22}$

Membuka rahasia pasien HIV/AIDS berarti melanggar sumpah jabatan dan wajib simpan rahasia kedokteran. Disamping itu tindakan tersebut dapat juga berarti menghilangkan kesempatan pasien HIV/AIDS tersebut untuk mencari nafkah dan kehidupan yang berarti bertentangan dengan hak azasinya sebagai manusia. Namun tetap menjaga rahasia pasien HIV/AIDS berarti mengorbankan kesehatan orang lain yang juga me-rupakan hak azasi setiap orang.

Dilema untuk tetap menyimpan rahasia kedokteran pasien HIV/AIDS adalah hal yang sangat sulit untuk diatasi meskipun secara fisik dokter tidak mendapat tekanan. Namun secara psikis dokter akan terbebani sepanjang hidupnya. Dokter pada waktu menghadapi pasien dengan status positif HIV sementara pasien tidak mengizinkan dokter untuk memberitahu kepada lingkungan terdekat seperti istrinya. J ika dokter memberitahukan kepada orang lain berarti melanggar hak pasien dan juga melanggar kode etik. Sebab dokter wajib menyimpan rahasia pasien termasuk penyakitnya. Apabila

\footnotetext{
21 Alexandra Indriyani Dewi, 2008, Etika Dan Hukum Kesehatan, Jogjakarta: Pustaka Book Publisher, hlm. 256. Lihat pula Endang Kusuma Astuti, "Hubungan Hukum Antara Dokter Dengan Pasien Dalam Upaya Pelayanan Medis", J urnal Daedalus, 2008.

22 Lihat mengenai pembagian overmacht ini pada Ibid. hlm. 257-258.
} 
dokter tidak memberitahukan penyakit penderita kepada orang lain, terutama kepada keluarga penderita, maka berarti melanggar hak orang lain untuk dilindungi dari tertularnya penyakit dari orang lain.

Mendasarkan pada pendapat Talcott Parsons, Ali berpendapat bahwa dalam hubungan dokter dan pasien diperlukan adanya komunikasi yang baik. Komunikasi bisa menjadi penyebab dan juga bisa menjadi solusi untuk memecahkan persoalan. Komunikasi bertujuan untuk membangun kesamaan makna, ${ }^{23}$ sehingga dalam hubungan dokter dan pasien ada tuntutantuntutan untuk menunjukkan perilaku sebagai berikut: ${ }^{24}$ (a) Dokter sering berfungsi sebagai "pengadilan" serta sekaligus memberi legitimasi terhadap pasien yang mengadukan keluhan tentang penyakitnya; (b) Dalam definisi keadaan sakit adalah merupakan hal yang sangat penting dan merupakan jembatan dokter untuk me-nolongnya atas kepercayaan yang diberikan oleh pasien; (c) Keadaan sakit membawa dokter berkewajiban menolong, pasien harus dilindungi; (d) Dengan diberi kepercayaan untuk mengobati oleh pasien sekaligus dokter berkewajiban menjaga rahasia medisnya.

Brown dalam teori perannya sebagaimana dikutip oleh Willy F. Maramis ${ }^{25}$ bahwa dokter mengalami konflik antar peran, yakni dokter disatu sisi harus menjaga rahasia pasien HIV/ AIDS dan di sisi lain harus memberi tahu ke lingkungan sehingga hak orang lain untuk hidup sehat terlindungi. Masing-masing peran menuntut perilaku yang bertentangan satu sama lain. Namun dapat terjadi bahwa dua peran yang berbeda harus dimainkan. Dokter dengan bekerja secara profesional berarti dokter telah berperan sesuai dengan peraturan yang berlaku dalam menjalankan tugasnya.

Perspektif yuridis tanggung jawab dokter dalam membuka rahasia medis pasien HIV/ AIDS, ternyata ada kecenderungan berpengaruh secara positif terhadap tingkat implemen-

\footnotetext{
23 Muhammad Mulyohadi Ali, op.cit. Lihat pula Ahmad Subiyanto, "Peran Komunikasi Dalam Menjalankan Profesi Dokter Yang Berkualitas Di Masyarakat", Jurnal Online UPT Perpustakan UNS 27 Maret 2009.

24 Willy F. Maramis, op.cit. hlm. 279

25 Ibid, hlm. 278
}

tasi hukum pelayanan kesehatan. Artinya semakin positif (sangat setuju) perspektif yuridis tanggung jawab dokter dalam membuka rahasia medis pasien HIV/AIDS semakin baik pula implementasi hukum kerahasiaan medis pasien HIV/ AIDS dalam pelayanan kesehatan tersebut. Hal ini dapat dilihat dari data di atas yang menunjukkan bahwa yang memiliki perspektif yuridis tanggung jawab dokter dalam membuka rahasia medis pasien HIV/AIDS $80 \%$ sangat setuju dan $20 \%$ setuju ternyata implementasi hukum terhadap kerahasiaan medis pasien HIV/ AIDS juga $80 \%$ sangat baik dan $20 \%$ baik. Oleh karena implementasi hukum terhadap rahasia medis pada dasarnya merupakan se-rangkaian kegiatan untuk mewujudkan dan melaksanakan tanggung jawab dokter dalam kenyataan yang berkaitan dengan pelayanan kesehatan, maka kecenderungan berpengaruhnya secara positif faktor perspektif yuridis tanggung jawab dokter dalam membuka rahasia medis HIV/ AIDS terhadap implementasi hukum kerahasiaan medis dalam pelayanan kesehatan inipun sangat dimungkinkan.

Menurut Roscoe Pound ${ }^{26}$ mendasarkan pada azas keseimbangan bahwa dalam konteks "laws as tool of social engineering" maka hukum mempunyai fungsi menata kepentingan-kepentingan yang ada dalam masyarakat. Kepentingan-kepentingan tersebut harus ditata sedemikian rupa agar tercapai keseimbangan yang proporsional. Ini berarti bahwa pelayanan kesehatan harus dilaksanakan antara kepentingan individu dan masyarakat secara seimbang. Maka untuk mewujudkan keseimbangan antara kepentingan pen-derita/ pasien HIV/ AIDS agar terjaga hak konfidensialitasnya dan kepentingan masyarakat agar terjaga dari tertularnya HIV/ AIDS maka cara penanggulangan HIV/ AIDS harus memperhatikan prinsip-prinsip yang telah dituangkan dalam Keputusan Menko Kesra No. 9/ KEP/ MENKO/ KESRA/ VI/ 1994 tentang Strategi

26. Bernard L. Tanya, et. all., 2010, Teori Hukum Strategi Tertib Manusia Lintas Ruang dan Generasi, Jogjakarta: Genta Publishing, hlm. 155. Lihat pula Adi Sulistiyono et. all., "Hukum Sebagai Instrumen Kebijakan", J urnal J urisprudence, Volume 1 No. 2 September 2004, hlm. 118. Bahwa pada hakikatnya hukum merupakan perlengkapan masyarakat untuk menjamin agar kebutuhan - kebutuhan dapat dipenuhi secara teratur. 
Nasional Pengaggulangan HIV/ AIDS di Indonesia. Prinsip-prinsip dasar penanggulangan HIV/AIDS yang dimaksud adalah: (a) Upaya penanggulangan HIV/AIDS dilaksanakan oleh masyarakat dan pemerintah. Masyarakat adalah pelaku utama dan pemerintah berkewajiban untuk mengarahkan, membimbing, serta menciptakan suasana penunjang; (b) Setiap upaya penanggulangan harus mencerminkan nilai-nilai agama dan budaya yang ada di indonesia; (c) Setiap kegiatan diarahkan untuk mempertahankan dan memperkukuh ketahanan dan kesejahteraan keluarga, serta sistem dukungan sosial yang mengakar dalam masyarakat; (d) Pencegahan HIV/ AIDS diarahkan pada upaya pendidikan dan penyuluhan untuk memantapkan perilaku yang tidak memberikan kesempatan penularan dan merubah perilaku yang berisiko tinggi; (e) Setiap orang berhak untuk mendapat informasi yang benar untuk melindungi diri dan orang lain terhadap infeksi HIV/ AIDS; (f) Setiap kebijakan, program, pelayanan dan kegiatan harus menghormati harkat dan martabat dari para pengidap HIV/ penderita AIDS dan keluarganya; (g) Setiap pemeriksaan untuk mendiagnosa HIV/ AIDS harus didahului dengan penjelasan yang benar dan mendapat persetujuan yang bersangkutan (informed consent). Sebelum dan sesudahnya harus diberikan konseling yang memadai dan hasil pemeriksaan wajib dirahasiakan; (h) Diusahakan agar peraturan perundangan mendukung dan selaras dengan strategi nasional penang-gulangan HIV/AIDS di semua tingkat; (i) Setiap pemberi layanan berkewajiban memberikan layanan tanpa diskriminasi kepada pengidap HIV/ penderita AIDS.

Agar kepentingan penderita HIV/ AIDS dan masyarakat terlindungi maka cara program pencegahan penyebaran HIV/AIDS seharusnya dipusatkan terutama pada pendidikan masyarakat mengenai pengertian, cara penularan dan pencegahan HIV/AIDS, dengan tujuan merubah kebiasaan orang-orang yang berisiko tinggi untuk tertular dan menghindari stigma dalam masyarakat terhadap orang dengan HIV/ AIDS (OD$\mathrm{HA}$ ), sekaligus memutus mata rantai penularan HIV/ AIDS.
Kedua, adalah berdasarkan perintah jabatan sebagaimana dimaksud dalam Pasal 170 KUHP, yang menentukan (1) Mereka yang karena pekerjaannya, harkat martabat atau jabatannya diwajibkan menyimpan rahasia, dapat dibebaskan dari kewajiban untuk memberi keterangan sebagai saksi, yaitu tentang hal yang dipercayakan kepada mereka; (2) Hakim menentukan sah atau tidaknya alasan untuk permintaan tersebut, maka pengadilan negeri yang memutuskan apakah alasan yang di-kemukakan saksi atau saksi ahli untuk tidak berbicara itu, layak dan dapat diterima atau tidak.

Pasal ini membebaskan seorang dokter dari kewajibannya untuk menjadi saksi di pengadilan atas dasar perintah jabatan. Hakim tentu saja memegang peran penting untuk menentukan alasan yang dikemukakan untuk dapat diterima atau tidak di dalam hak untuk menolak menjadi saksi. Hal ini bergantung pada kesaksian apa yang dibutuhkan. Jika kesaksian itu mengenai suatu hal yang tidak ada hubungan langsung dengan seorang pasien, maka hal ini tidak termasuk rahasia medis (kedokteran). Jika kesaksian itu ada hubungan langsung dengan seorang pasien maka dokter itu dapat menggunakan hak undur diri.

Ketiga, atas dasar ketentuan undang-undang. Pengecualian terhadap wajib simpan rahasia kedokteran juga berlaku pada kondisi darurat seperti wabah dan bencana alam. Di mana seorang dokter tidak boleh membiarkan bencana terjadi tanpa penanganan yang semestinya hal ini diatur dalam UU No. 4 Tahun 1984 tentang Wabah Penyakit Menular. Undang-undang ini mewajibkan dokter dan petugas kesehatan lainnya untuk segera melaporkan kondisikondisi luar biasa karena wabah penyakit dan penyebarannya, sehingga bisa ditanggulangi. Namun dalam Instruksi Menteri Kesehatan No. 72/ MenKes/ Inst/ 1988 tentang Kewaj iban Melaporkan Penderita Dengan Gejala AIDS. Ketentuan tersebut hanya ditujukan kepada petugas kesehatan dan sarana pelayanan kesehatan saja. Tindakan yang diambil pada saat ditemuinya seseorang dengan gejala AIDS hanyalah pelaporan kepada Dirjen Pemberantasan Penyakit Menular dan Penyehatan Lingkungan Pemukim- 
an (P2MPLP) saja dengan memperhatikan kerahasiaan pribadi pasien sementara lingkungan tidak diberitahu kalau ada pasien penderita HIV/ AIDS dengan alasan HAM dan kemungkinan besar bisa menular berarti akan menimbulkan masalah HAM di masyarakat.

Pelanggaran kewajiban untuk menjaga rahasia medis dapat dikenakan beberapa sanksi. Pertama, sanksi disiplin oleh Majelis Kehormatan Disiplin Kedokteran Indonesia (MKDKI) sesuai dengan Pasal 64 sampai dengan Pasal 70 UU No. 29 Tahun 2004. Dalam Peraturan Konsil Kedokteran Indonesia NO. 16/ KKI/ PER/ VIII/ 2006 tentang Tata Cara Penanganan Pelanggaran Disiplin MKDKI, ada tiga alternatif sanksi disiplin yaitu: (a) Pemberian peringatan tertulis; (b) Rekomendasi pencabutan surat tanda registrasi atau surat izin praktik; (c) Kewajiban mengikuti pendidikan atau pelatihan di institusi pendidikan kedokteran atau kedokteran gigi. Selain sanksi disiplin, dokter yang tidak menjaga rahasia medis dapat dikenakan sanksi etik oleh organisasi profesi yaitu Majelis Kehormatan Etika Kedokteran (MKEK). Kedua, sanksi administratif tetap diberikan meskipun pasien HIV/ AIDS yang dirugikan telah memaafkan dan tidak mengadukan kepada pihak berwajib sesuai dengan Pasal 4 Peraturan Pemerintah No. 10 Tahun 1966 tentang Wajib Simpan Rahasia Kedokteran. Ketiga, sanksi pidana sesuai dengan Pasal 322 KUHP jo. Pasal 79 huruf (c) UU No. 29 Tahun 2004. Pembocoran rahasia medis pasien HIV/AIDS oleh dokter merupakan delik aduan, di mana dokter hanya dapat dituntut jika ada pengaduan dari pasien yang bersangkutan. Keempat, sanksi Perdata sesuai dengan Pasal 1365 KUHPerdata jo. Pasal 58 UU No. 36 Tahun 2009. Jika membuka rahasia medis pasien HIV/ AIDS bukan inisiatif sang dokter tetapi atas kemauan rumah sakit, maka sanksi perdata sesuai dengan Pasal 1367 KUHPerdata jo. Pasal 46 UU No. 44 tentang Rumah Sakit.

\section{Penutup}

\section{Simpulan}

Ada dua simpulan yang dapat diberikan berdasarkan pada permasalahan dan pembahasan tersebut di atas. Pertama, perspektif yuridis tanggung jawab dokter secara umum menunjukkan sangat setuju dalam membuka rahasia medis pasien HIV/ AIDS harus seizin pasien. Hal ini disebabkan dokter sebagai pemegang peran memiliki kebiasaan berpikir yang sesuai dengan norma sosial yang berlaku di lingkungan kerjanya. Kedua, secara umum rata-rata implementasi hukum terhadap kerahasiaan medis pasien HIV/AIDS dalam pelayanan di Rumah Sakit Umum Daerah Banyumas adalah sangat baik. Hal ini disebabkan dokter sebagai pemegang peran sadar akan mengabdi kepada kepentingan sistem sosial yang berlaku, lagi pula ada kecenderungan positif dari perspektif yuridis tanggung jawab dokter dalam mem-buka rahasia medis pasien HIV/AIDS yang sesuai dengan norma sosial yang berlaku di lingkungan kerjanya.

\section{Saran}

Saran yang dapat diberikan adalah bahwa sebaiknya dalam memutus mata rantai penyebaran HIV/AIDS maka Pemerintah perlu merevisi regulasi yang ada supaya dapat melindungi pasien dari stigmatisasi dan terjaminnya lingkungan dari tertularnya penyakit tersebut. Regulasi yang ada dengan menganut azas sukarela dan rahasia masih ada hambatan. Perlu ada regulasi tentang edukasi ke lingkungan baik melalui pendidikan formal maupun pendidikan non formal. Diharapkan akan terbangun pemahaman, sikap dan tindakan yang benar terhadap orang dengan HIV/ AIDS pada khususnya dan penanggulangan HIV/ AIDS pada umumnya.

\section{Daftar Pustaka}

Astuti, Endang Kusuma. "Hubungan Hukum Antara Dokter dengan Pasien Dalam Upaya Pelayanan Medis". J urnal Daedalus, 2008;

-..-.-.. "Hubungan Hukum Antara Dokter dan Pasien Dalam Upaya Pelayanan Medis". J urnal Legality, 2010;

Cohen, J eryl S. and J eanne M. Erickson. "Ethical Dilemmas and Moral Distress in Oncology Nursing Practice"; Clinical Journal of Oncology Nursing, Vol. 10, Number 6/ December 2006; 
Dewi, Alexandra Indriyani. 2008. Etika Dan Hukum Kesehatan. J ogjakarta: Pustaka Book Publisher;

Dimyati, Khudzaifah. "Hukum dan Kebijakan Kemiskinan: Studi Tentang Produk Legislatif Daerah Sebagai Sarana Penanggulangan Kemiskinan". J urnal IImu Hukum, Vol. 9, No. 1, Maret 2006;

Dir.Jen. P2MPLP. 1997. AIDS Petunjuk Untuk Petugas Kesehatan. J akarta: Dep.Kes. R. I;

Dirjen Bina Pelayanan Medis Kementrian Kesehatan Republik Indonesia. 2010. Skrining HIV di Rumah Sakit Dalam Upaya Pencegahan Penyebaran HIV (Hasil Kajian Tahun 2009);

Fiedman, Lawrence, M. 2009. Sistem Hukum Perspektif IImu Sosial. Bandung: Nusa Media;

Firdaus, Sunny Ummul. 2008. Rekam Medik daIam Sorotan Hukum dan Etika, Surakarta: Sebelas Maret University Press;

Fuady, Munir. 2005. Sumpah Hippocrates (Aspek Hukum Malpraktik Dokter). Bandung: PT. Citra Aditya;

Gunawan, Suriadi. "Perkembangan Masalah AIDS". J ournal Cermin Dunia Kedokteran, No. 75, 1992, J akarta;

Gunnara, Harvensica. "Perlindungan hak pasien di RS Kanker Dharmais J akarta". J urnal Kesehatan Masyarakat Nasional, Vol. 02, No. 03, 2007;

Guwandi, J. 2009. Pengantar IImu Hukum Medis dan Bioetika. J akarta: FKUI;

Iswandari, Hargianti Dini. "Aspek Hukum Penyelenggaraan Praktek Kedokteran: Suatu Tinjauan Berdasarkan Undang-Undang No. 9/2004 Tentang Praktek Kedokteran", J urnal Manajemen Pelayanan Kesehatan, Vol. 09, No. 02, J uni 2006;

J acobalis, Samsi. 2005. Pengantar Tentang Perkembangan IImu Kedokteran, Etika Medis, dan Bioetika. J akarta: CV Sagung Seto Bekerjasama dengan Universitas Tarumanegara;

J amal, Sarjaini. "Pengetahuan Masyarakat Tentang HIV/ AIDS". J urnal Kedokteran YARSI, Vol. 13 No. 2, 2005;

J aparianto, Edwin. "Analisis Pembentukan Disonansi Kognitif Konsumen Pemilik Mobil Toyota Avanza". Jurnal Manajemen Pemasaran, Vol. 1, No. 2, Oktober 2006;
Kementrian Negara Pemberdayaan Perempuan RI. 2008. Pemberdayaan Perempuan dalam Pencegahan Penyebaran HIV-AIDS, J akarta;

Khotimah, Ema. "Analisis Kritis Teori Pembangunan dan Kedudukan Perempuan dalam Perspektif Ekofeminisme", Jurnal Kajian Gender, Vol 1, No 1 (2010);

Kusmiadi, Ade. "Pengintegrasian Pendidikan Pencegahan HIB AIDS dalam Satuan Program Pendidikan Nonformal dan Informal". J urnal IImiah VISI PTK-PNF, Vol.3 No.2, 2008;

Lachman, Vicki D. "Practical Use of the Nursing Code of Ethics: Part I". MEDSURG Nursing, Vol. 18/ No. 1, J anuary/ February 2009;

Mar'at; 1981; Sikap Manusia Perubahan Serta Pengukur-annya, Bandung: Ghalia Indonesia;

Maramis, Margarita M. 2007. Konseling dan Tes Sukarela Untuk Penderita HIV \& AIDS dalam Nasronudin \& Margarita M. Maramis (editor), Konseling, Dukungan, Perawatan \& Pengobatan ODHA. Surabaya: Airlangga University Press;

Muhamad, Shaukat. 2010. "The Interface between the Family and the Health Care System in the Care of People With HIV/ AIDS". Journal of Health Management, September 1. 2010;

Notoatmodjo, Seokidjo. 2010. Etika \& Hukum Kesehatan, Jakarta: Rineka Cipta;

Nurbani, Farah. "Dukungan Sosial Pada ODHA", J urnal Yayasan Spiritia, Universitas Gunadarma, 2006;

Oetama dan Fred Ameln. "Hukum Kedokteran dan Beberapa Hak Pasien". J ournal Cermin Dunia Kedokteran No. 22, 1981;

Poerwanto, Hendra. "Mengevaluasi Kualitas Layanan Jasa dengan Menggunakan Model $4 D^{\prime \prime}$. J urnal Manajemen \& Kewirausahaan Vol. 2, No. 2, September 2000

RGN J ohn Adam. "Prescribing: The Ethical Dimension". Nurse Prescriber, Vol. 1 No. 7, 2004;

Roatib, Ali. dkk. "Hubungan Antara Karakteristik Perawat dengan Motivasi Perawat Pelaksana dalam Menerapkan Komunikasi Terapeutik Pada Fase Kerja Di Rumah Sakit Islam Sultan Agung Semarang". Nurse Media J ournal of Nursing, Vol. 1, Nomor 1, Tahun 2007; 
Setiaman, Agus. Perspektif Sosiologis, http:// wordpress.com/2008/11/25/ diakses pada 29 Desember 2010,;

Seymour, J ohn W. dan Lawrence Rubin, "Principles, Principals, and Process (P3): A Model for Play Therapy Ethics Problem Solving". International Journal of Play Therapy, Vol 15 No. 2, 2006;

Steinbrook, M.D. "The AIDS Epidemic in 2004". The New England J ournal of Medicine;

Subiyanto, Ahmad. "Peran Komunikasi dalam Menjalankan Profesi Dokter yang Berkualitas di Masyarakat". J urnal Online UPT Perpustakan UNS 27 Maret 2009;

Subuh, HM. 2010; Achieve Universal To HIV Prevention, Treat ment, Care and Support; Disampaikan pada Pertemuan IImiah Tahunan (PIT 1) MHKI, Jakarta, 21 November 2010;
Sulistiyono, Adi et. all. "Hukum Sebagai Instrumen Kebijakan", Jurnal J urisprudence, Vol. 1 No. 2 September 2004;

et. all. "Hukum dan Kebijakan Kemiskinan". J urnal J urisprudence, Volume 2. No. 1 Maret 2005;

Tanya, Bernard L. et. all. 2010. Teori Hukum Strategi Tertib Manusia Lintas Ruang dan Generasi. J ogj akarta: Genta Publishing;

Tengker, Freddy. 2007. Hak Pasien. Bandung: Mandar Maju;

Widihastuti, Setiati. "Kajian Perlindungan Hak Pasien Sebagai Pencegahan Malpraktek Medik". Jurnal Penelitian Humaniora, Vol. 13, No. 2, Oktober 2008;

Williams, John R. 2000. Medical Etics Manual, (Terjemahan oleh Tim Penerjemah PSKI FK UMY), Editor Sagiran. Yogyakarta: Pusat Studi Kedokteran Islam UMY. 